Jpn. J. Med. Mycol.

Vol. 21, 157-161, 1980

ISSN $0583-0516$

\title{
癜風に打ける免疫学的諸問題
}

\author{
今村 貞夫 古川 福実段野貴一郎 \\ 京都大学医学部皮膚科学教室
}

田中玄明

大阪府済生会中津病院皮膚科

癜風の病原菌である Malassezia furfur と Pityrosporum 属との異同を明らかにする目的で， まず $P$ 属相互 間の抗原性を Ouchterlony 板を用いて検討したところ，P. orbiculare とP. ovale は極めて近い関係にあるが， P. canis はかなり異つたものと考光られた. 次に抗 P. orbiculare 血清を用いて，螢光抗体間接法により検索し たところ，M. furfur は，P. orbiculare やP. ovale と抗原性に抢いて極めて近いものであることが判明した.

癜風病巣18例の生検を行い，角層内㳊存する $M$. furfur に対する生体の反応性をしらべたところ，表皮 肥厚が13例にみられたが，真皮上層や表皮内への遊走細胞の浸潤は汪とんどみられなからた．P. orbiculare に 対する血清抗体を瘕風患者と健康人について，感作赤血球凝集反応と螢光抗体法を用いて測定したところ，そ の抗体価には，両群の間に顕著な差を見出し得なかつた。

澽風の原因である Malassezia furfur (以下M. furfur) は, 現在 Pityrosporum orbiculare (以下 P. orbiculare) と 同一菌であるといら説が強いようであるが，我々はこれ をより明確にするために，Pityrosporum 属の 2，3の菌 につき, Ouchterlony 寒天板を用いて，その抗原性の異 同を明らかにすると共に，さらにそれらと，M.furfur との関係についても螢光抗体法を用いてその抗原性の異 同を明らかにすることを試みた。

次に, 癜風患者において, M. furfur が生体に如何に かかわりをもつているかを, 主として免疫学的観点から 検索を試みた。すなわら, 癜風病巣の組織標本を観察し て，生体が癜風菌に如何に反応しているかを検索すると 共に, 癜風患者の血清中に, Pityrosporum に対する血清 抗体が如何に産生されているかを検索した，そして，こ れらの反応と, 患者の年齢, 性, 病変の持続期間, 拡がり, 色調, 㽷痒の有無などとの関係についても注意を払つた。

\section{Pityrosporum 属の抗原分析}

\section{1. 実験方法}

1) Pityrosorum 抗原の作成

別刷請求先 : 今村 貞夫

干 606 京都市左京区聖護院川原町 京都大学医学部皮膚科学教室
P. orbiculare, P. ovale, P. canis (いずれも神戸中央市 民病院皮膚科部長宗義朗博士からの提供による）を固形 培地 (malt extract (Difco) $20 \mathrm{~g}$, yeast extract (Difco) $2 \mathrm{~g}$, dextrose $20 \mathrm{~g}$, pepton $20 \mathrm{~g}$, agar $20 \mathrm{~g}$, olive oil $1 \sim 2 \%$, 蒸溜水 $1,000 \mathrm{ml}$ ) に大量培養し, $99 \%$ エタ, ールで数回洗浄, 乾燥後, 菌体をボールミルに移して粉 砕し, その後100倍量の $\mathrm{PBS}\left(\mathrm{pH} \mathrm{7.4)}\right.$ にて $4{ }^{\circ} \mathrm{C}, 24$ 時 間振盪した. 10,000回転20分遠心後，上清をミリポアフ ィルター $(0.22 \mu)$ で濾過し，抗原とした. 抗原の蛋 白量は $P$. orbiculare $0.28 \mathrm{mg} / \mathrm{ml}, P$. ovale $0.45 \mathrm{mg} / \mathrm{ml}$, $P$. canis $0.88 \mathrm{mg} / \mathrm{ml}$ であつた.

2) 抗 P. orbiculare 血清の作成

P. orbiculare $100 \mathrm{mg} / \mathrm{ml}$ を等量の incomplete Freund's adjuvant と混じ， 5 羽の家鬼の筲筋内へ $1.0 ， 2.0 ， 3.0$, $4.0,5.0 \mathrm{ml}$ 注射した. 1 力月後, $1.0 \mathrm{mg} / \mathrm{ml}$ の $P$. orbiculare 生食懸濁液を 1 週 3 回 4 週にわたつて 静注し た. 注射量は初回 $0.5 \mathrm{ml}$ で以後 1 回毎に $0.5 \mathrm{ml}$ ずつ $5.0 \mathrm{ml}$ になるまで増量した. 第28日目に採血したとこ

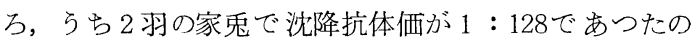
で，以後の実験にはこれを用いた。

\section{2. 実験結果}

Ouchterlony 寒天板を用いて, 各種 Pityrosporum 抗原 

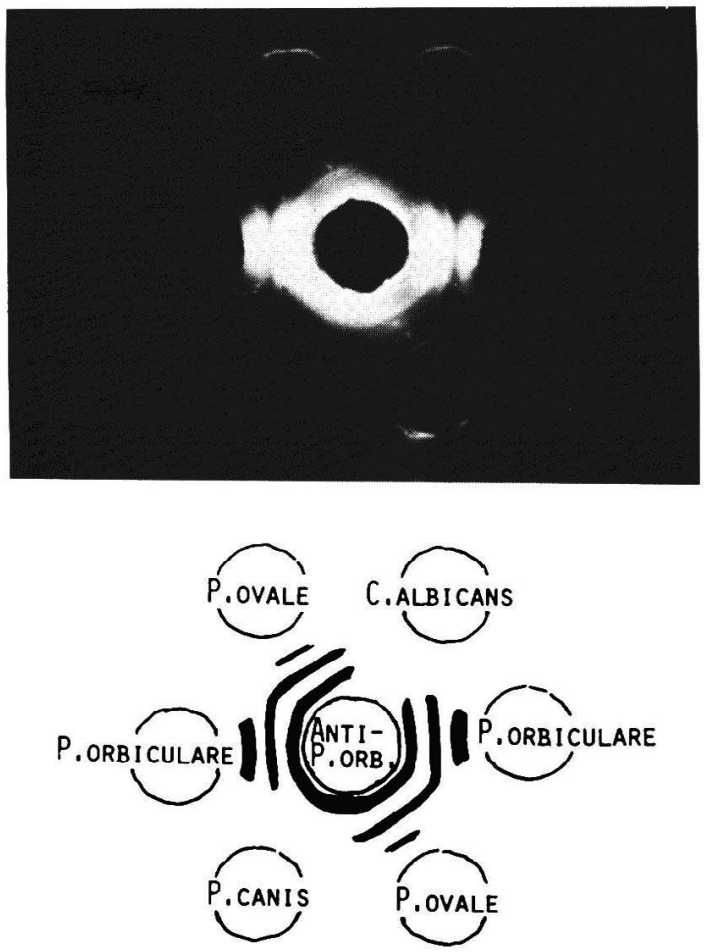

困1.Pityrosporum 属の抗原分析.

と抗 P. orbiculare 血清との反応を镜察した.

图 1 亿示すように, 抗 $P$. orbiculare 血清以対して $P$. orbiculare 抗原は 3 本の沈降線を示した. P. ovale に対し ても 3 本の沈降線が認められたが，内側の 2 本は，P. orbiculare に対する沈降線と fuse していた. P. canis に 対しては，1本の沈降線しか認められなからたが，これ は, P. orbiculare 抢よびP. ovale の沈降線と fuse するも のであつた。な扰，対象として用いた Candida albicans (以下 C.albicans) 抗原（蛋白量 $0.87 \mathrm{mg} / \mathrm{ml}$ ) に対し ては，沈降線は全く認められなかつた。

\section{Pityrosporum 属, Malas sezia furfur $の$ FITC} 標識抗 P. orbiculare 血清に対する反応性

1. 実験方法

1）FITC 梌識抗 $P$. orbiculare 血清の作成

I で用いた抗 P. orbiculare 血清より，1/3飽和硫酸 アソモニウム液を利用して粗グロブリンを分離 し,

Marshall らの方法で FITCを標識した．な找，色素蛋 白比は 1：60とした。標識抗体は DEAE セルロースカ ラムを用いて精製し, 濃縮後使用した。この際, 蛋白量 は13.7 mg/ml，F/P モル比は0.6であつた。

\section{2）染色標本の作成}

Pityrosporum 属, 癜風患者の鱗兏拉よび対照とした C. albicans は，無螢光ガラスに塗沫後95\%エタノールで 10分間固定，その後型のごとく染色した。

㿂風病巣の生検標本はアセトンドライアイスで涷結後 $-80^{\circ} \mathrm{C}$ に保存した。切片は $-20^{\circ} \mathrm{C}$ のリオスタット内で 作成し，乾燥後 $95 \%$ エタノールで10分間固定して染色し た

\section{2. 実験結果}

塗洙標本上で $P$. orbiculare とP. ovale は共に強く黄緑 色の特異螢光 $(3+)$ を示した. 螢光は特に菌の辺縁部 で強く認められた，P. canis は極めて弱く $(+1)$ 染色 された. C. albicans 注特異螢光は認められなからた。 癜風患者の鱗屑の塗沫標本を染色すると, M. furfur は 菌系，胞子ともかなり強く $(+2)$ 染色された.

誐風病巣の切版標本を染色すると，角層内に存在する M. furfur はかなり強く染色された。1 例では，毛囊内 に菌系が強く特異螢光を示して認められた。

表 1 Pityrosporum 属, M. furfur の炜光抗体染色

\begin{tabular}{|c|c|c|c|c|c|}
\hline \multirow{3}{*}{ Smear of } & \multicolumn{5}{|c|}{ Anti-P. orbiculare conjugate } \\
\hline & \multirow{2}{*}{$\begin{array}{l}\text { not } \\
\text { absorbed }\end{array}$} & \multicolumn{4}{|c|}{ absorbed with } \\
\hline & & $\begin{array}{l}C . \\
\text { albicans }\end{array}$ & $\begin{array}{l}P \text {. } \\
\text { canis }\end{array}$ & $\begin{array}{l}P . \\
\text { ovale }\end{array}$ & $\begin{array}{l}P \text { orbiculare } \\
\end{array}$ \\
\hline P. orbiculare & \# & H & + & - & - \\
\hline P. ovale & \# & $H$ & + & - & - \\
\hline$P$. canis & + & + & - & - & - \\
\hline C. albicans & - & - & - & - & - \\
\hline M. furfur & H & + & + & - & - \\
\hline
\end{tabular}

FITC 標識抗 $P$. orbiculare 血清を $P$. orbiculare, $P$. ovale, P. canis, C. albicans などによつて吸収後，前記塗 沫標本を染色すると，表 1 のごとき結果が得られた. 即 ち, 抗血清を P. orbiculare および，P. ovale で吸収する 之, Pityrosporum 属, M. furfur の特異螢光は全く消失 した，抗血清を $P$. canis で吸収すると， P canis の特 異螢光は消失したものの, P. orbiculare, $P$. ovale, $M$. furfur の特異螢光は減弱はするが，な打認められた。抗 血清を C. albicans で吸收すると P.orbiculare. P. ovale, M. furfur の螢光は多少減弱したが，なおかなり強く認 められた。

\section{III. 癜風菌に対する生体の反応性}
1. 実験方法
1) 対象 
昭和54年 3 月より 9 月に主として京都大学医学部附属 病院皮膚科外来を受診した 40 名の癜風患者につき，病巣 部の生検と採血を行つた. 生検標本は半分を $10 \%$ ホルマ リンに固定して HE, PAS 染色に供し, 残り半分は, 前 項に記載した如く, 凍結切片とし, FITC 標識抗 $P$. orbiculare 血清の浪か，FITC 標識抗七ト IgG，IgM， IgA，C3 (いずれも Dakopatts 社製）で染色した.な 抒，対照として 31 名の健康人（3 例を除いて10代〜30 代）からも採血を行つた。

2）感作赤血球凝集反応

Boyden の方法で羊赤血球をタンニン酸で処理した 後, I で作成したP. orbiculare 抗原を吸着させ, 患者希 釈血清 $0.1 \mathrm{ml}$ を入れたマイクロUプレートの孔に 0.02 $\mathrm{ml}$ づつ加光， $37^{\circ} \mathrm{C}, 30$ 分間反応させた後, $4^{\circ} \mathrm{C} て ゙ 1$ 夜 放置, 翌日血球の凝集を観察した。凝集の認められる血 清の最大希釈をるつて，抗体価とした。

3）螢光抗体抗体価

II で示した如く作成した P . orbiculare 塗沫標本（95\% メタノール固定）飞患者希釈血清を載せ， $37^{\circ} \mathrm{C} 30$ 分間反 応させた後，抗ヒト IgG，A，M (Dakopatts 社製) と $37^{\circ} \mathrm{C} 30$ 分間反応させた。 P. orbiculare が黄緑色の特異螢 光を示す血清の最大希釈をるつて抗体価とした.

\section{2. 実験結果}

1) 生検標本

18例について検索した．結果は表 2 のごとくであり， 表皮角層の不全角化や表皮の細胞浸潤，表皮内への遊走 細胞の浸潤はほとんど認められなかつた。しかし，表皮 の肥厚は18例中13例で多少なりとも認めら机た。螢光抗 体法では, M. furfur は抗 P. orbiculare 血清で強く染色 されたが，免疫グロブリンや補体が沈着しているところ はなかつた。

表 2 . 癜風病巣の組織学的検索

\begin{tabular}{|c|c|c|}
\hline \multirow[t]{2}{*}{ Parkeratosis } & Focally present & 2 \\
\hline & Absent & 16 \\
\hline \multirow[t]{3}{*}{ Acanthosis } & Present & 3 \\
\hline & Slightly present & 10 \\
\hline & Absent & 5 \\
\hline \multirow[t]{2}{*}{ Exocytosis } & Slightly present & 1 \\
\hline & Absent & 17 \\
\hline \multirow{3}{*}{$\begin{array}{l}\text { Dermal cell } \\
\text { infiltrate }\end{array}$} & Mild & 5 \\
\hline & Slight & 10 \\
\hline & Normal & 3 \\
\hline
\end{tabular}

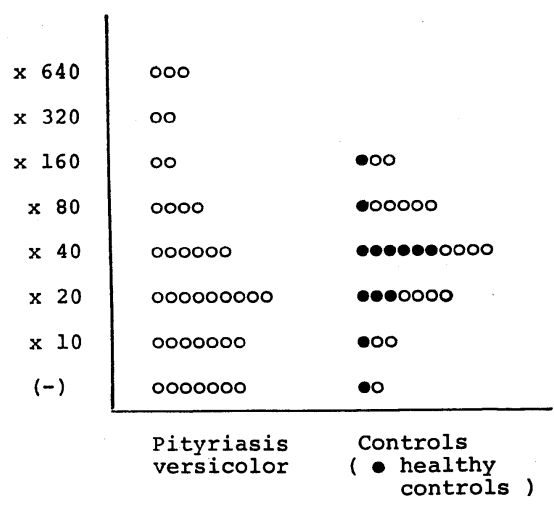

図 2 . 感作赤血球凝集反応抗体価.

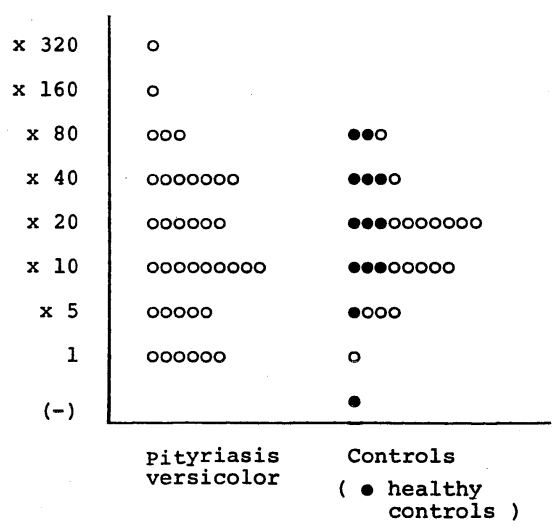

図 3. 螢光抗体抗体価.

2）感作赤血球凝集反応抗体価

図 2 のごとく，癜風患者では，最高640倍までの抗体 価を示した. しかし，健常人でも最高160倍までの抗体 を示し，洀風患者と健康人の間で，抗体価の分布に有意 の差があるよらには思われなかつた。な物，洀風患者の らち640倍の抗体価を示した 3 例のうち 1 例は21歳女子 で 1 年前より胸部に限局性に痖痒のない褐色皮疹をもつ 患者であり，もう 1 例は 22 歳女子で $2 \sim 3$ 週前より胸背 部に広範囲に瘙痒のない褐色皮疹をもつ患者で, 他の 1 例は，22歳女子で腹部に散在性に瘙痒のある褐色皮疹を もつ患者であつた。

3）螢光抗体抗体価

図 3 に結果を示す. 瘢風患者では, 最高320倍の抗体価 を示した，健康人の抗体価は80倍までであつたが，癜風 患者と健康人との間に抗体価の分布に有意の差はないよ らであつた. 螢光抗体価と, 感作赤血球凝集反応抗体価 とは，朊颃むね平行していた。 320倍の螢光抗体価を示 
した例は，感作赤血球凝集反応でも640倍の抗体価を 示 した21歳女子例であつた。

以上, 生検標本, 感作赤血球凝集反応抗体価, 螢光抗 体価を通じて, その所見と, 患者の年齢, 性, 病変の持 続期間, 拡がり, 色調, 瘙棒の有無との間洔別の関係 は認められなかつた。

\section{考 察}

Pityrosporum 属にあつて, P. orbiculare とP. ovale は 形態的には異つているが，本質的に別の菌であるかど らかは現在かなり疑問視されている。最初典型的な球状 の形を示し，P. orbiculare と考它られていたものが，培 養をつづけているらちに ovale type のものになつた とする報告はかなり多い补し，速水 ${ }^{2}$ は電顕的にみる限 り, P. orbiculare と P. ovale との間に大差は認められな からたと述べている. 免疫学的には, Alexander ${ }^{3)}$ は, ふ以患者の Pityrosporum 汶対する抗体価を測定した際， P. orbiculare とP. ovale の間には明確な交差反応が認め られたと述べ，また，P. orbiculare で免度したモルモッ 卜血清は, P. orbiculare とP. ovale 飞対し同一抗体価を もつて反応したと述べている. 我々が Ouchterlony 寒 天板を用いて行つた結果では, 抗 $P$. orbiculare 血清は, P. orbiculare.とP. ovale に対し, 共に 3 本の沈降線をも つて反応し，らち 2 本は完全に fuse していた. また, こ の抗血清に螢光色素を標識して Pityrosporum 属の反応 性を検索したところ，P. orbiculare とP. ovale は，ほと んど同じ強さでもつて反応し，さらに吸収実験を行うこ とにより，両菌の抗原性は注济同一であることが確かめ られた.な扬, P. canisは,これら 2 菌とは, Ouchterlony 板上でも，螢光抗体法を用いてもかなり異つた反応性を 示し, P. canis は P. orbiculare p P. ovale とはかなり異 つた菌であるように思われた。

M. furfur が P. orbiculare と本質的に同一の菌であ り, 前者が菌系型, 後者が胞子型であるとの考光は今日 有力である. Burke ら゙)は，クッシング症候群などの患 者にP. orbiculare を接種したところ，癜風病変を生じた り，生じない場合でるM. furfurを思わせる菌采を認め た. 最近 Nazzaro Porro $ら^{51}$ は, P. orbiculareやP. ovale の培地にコレステロールやコレステロールエステルを加 觉ると， M. furfur 様の菌系の出現がみられると報告 し， Faergmann ${ }^{6)}$ は，家鬼の耳介内部拈よび癜風患者 や正常人に，P. orbiculare をODT により接種したとこ ろ, 半数以上の例で雐風様病栄や菌系の出現をみたと報 告している.Pitprosporum と M. furfur に関する兔疫学
的研究としては, Keddie $ら^{7)}$ P Sternberg $5^{8)}$ の溃光抗 体間接法を用いての研究がある. 彼らは, P. orbiculare 免疫モルモット血清や，癜風患者血清は，P. orbiculare とM. furfur に対して同様に強〈反応すること，また， これら血清を P. orbiculare で吸収すると，P. orbiculare のみならず $M$. furfur 位対する反応性る消失することを 認めている. 我々の今回の螢光抗体直接法による実験結 果でも, 抗 P. orbiculare 血清は, M. furfur に対して, 塗沫標本, 切片標本を問わず P. orbiculare や P. ovale と ほ涪同様に強く反応し，P. orbiculare に上る吸収を行 らとこれら反応は消失した.このことは，M. furfur が P. orbiculare p P. ovale 之抗原性に招いて極めて近い ものであることを示唆している，ただ我々の場合， $M$. furfur の反応性は, P. orbiculare 户 P. ovale 飞比べて やや弱い印象を受けたが，これは菌の形態が変化すれば 同一菌であつても抗原性に多少の差異の出ることは充分 考光られ，両菌が本質的に異つたものといらことにはな らないと思われる。

癜風病巣を生検し HE あるいは PAS 染色を行う 之，菌は角層内に多数認められるにもかかわらず生体側 の所見は一般に乏しいといらのが日頃我々のもつ印象で ある。また, 臨床的にも, 発赤や瘙痒などの炎症症状を 示すことは一般的に少ない，我々は今回18例の癜風病巣 を生検し，不全角化，表皮肥厚，真皮上層特よび表皮内 への遊走細胞の浸潤などに焦点を向けて詳細に検討した ところ，表皮の肥厚は13例で多少なりとも認められた が，その他の炎症所見はほとんぞ認められなかつた。 Nazzaro-Porro ら ${ }^{99}$ は，P. orbiculare の培養液の脂質分 画は in vitro でチロジナーゼ活性を抑制することを報告 し，in vivo に招いて子 Pityrosporum の産生する物質の 表皮内への吸収によつて癜風病巣の脱色素が起る可能性 を示唆しているが，多数の例で認められた表皮肥厚の発 生にもM. furfur 由来物質の表皮内への吸収が関与して

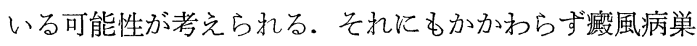
では, 白痽やカンジダ症と異なり,リンパ球などの反応 が汪とんど認められない理由は明らかでないが，Pityrosporum は白撚菌やカンジダに比べて，菌体自体あるい は補体を介しての chemotactic な作用が弱いのかる知れ ない。

喔風患者40例飞ついて Pityrosporum orbiculare に対す る血清抗体を, 感作赤血球凝集反応之螢光抗体間接法 により検索したところ，極く少数例で高值を示するのが みられたが，全体としては，健康人之差が認められなか 
つた. Alexander ${ }^{3}$ はふらの多い人はPityrosporum に対す る抗体価が一般に高いと報告しているが，Pityrosporum は頭部に圧倒的に多数常在していることを考旮れば, 癜 風の際に $M$. furfur が多少増加してb, Pityrosporum 全 体に占める割合はそれほど高くないことがその理由かも しれない.

本論文の一部は文献（10）に原著として報告した。 Pityrosporum 属, おょび数本の癜風患者血清の提供をう けた神戸中央市民病院皮膚科宗義明先生に心から感謝い たします。

\section{文献}

1）宗 義朗, 土井 顕, 大鄉典子, 松田良夫： Pityrosporum 属について. 真菌誌, 17：1-9, 1976.

2) 速水 誠: Malassezia furfur の微細構造一Pityrosporum 属, 特に P. orbiculare との異同をめ ぐって. 皮膚, 16: 377-392, 1974.

3) Alexander, S.: Loss of hair and Dandruff. Br. J. Dermatol., 79: 549-552, 1967.

4) Burke, R.C.: Tinea versicolor: Susceptibility factors and experimental infection in human beings. J. Invest. Dermatol., 36: 389—402,
1961.

5) Nazzaro Porro, M., Passi, S., Caprilli, F. and Mercantini, R.: Induction of hyphae in cultures of Pityrosporum by cholesterol and cholesterol esters. J. Invest. Dermatol., 69: $531-534,1977$.

6) Faergemann, J.: Experimental tinea versicolor in rabbits and humans with Pityrosporum orbiculare. J. Invest. Dermatol., 72: 326329, 1979.

7) Keddie, F. and Shadomy, S.: Etiological significans of Pityrosporum orbiculare in tinea versicolor. Sabouraudia, 3: 21-25, 1963.

8) Sternberg, T.H. and Keddie, F.M.: Immunofluorescence studies in tinea versicolor. Arch. Dermatol., 84: 999-1003, 1961.

9) Nazzaro-Porro, M. and Passi, S.: Identification of tyrosinase inhibitcrs in cultures of Pityrosporum. J. Invest. Dermatol., 71: 205208, 1978.

10) Tanaka, M. and Imamura, S.: Immunological studies on Pityrosporum genus and Malassezia furfur. J. Invest. Dermatol., 73: $321-324,1979$.

\title{
Immunological Aspects on Pityriasis versicolor
}

\author{
Sadao Imamura, Michiaki Tanaka*, Fukumi Furukawa and \\ Kiichiro Danno \\ Department of Dermatology, Faculty of Medicine, Kyoto University, Kyoto 606, Japan and \\ * Department of Dermatology, Osaka Saiseikai Nakatsu Hospital, Osaka 530, Japan
}

In order to clarify the relationship between Malassezia $(M$.$) furfur and Pityrosporum (P.) genus, the$ antigenicity of $P$. genus and $M$. furfur was investigated. The Ouchterlony plate showed the close relationship between $P$. orbiculare and $P$. ovale, but the antigenicity of $P$. canis was rather different from those of above-mentioned two species. Immunofluorescence study, using anti- $P$. orbiculare serum, revealed close relationship between $M$. furfur and $P$. orbiculare or $P$. ovale. Biopsy specimens were obtained from 18 patients with Pityriasis versicolor. Although more or less acanthosis was seen in 13 specimens, the signs of inflammation, such as the presence of inflammatory cells in the upper dermis or epidermis were scarcely observed. The antibody titer against $P$. orbiculare was determined using passive hemagglutination test and indirect immunofluorescence in the sera from patients with pityriasis versicolor and control subjects. There seemed to be no significant differences in the titer between these two groups. 